\title{
Antimicrobial activity and stability of the D-amino acid substituted derivatives of antimicrobial peptide polybia-MPI
}

\author{
Yanyan Zhao ${ }^{1 \dagger}$, Min Zhang ${ }^{2 \dagger}$, Shuai Qiu', Jiayi Wang ${ }^{1}$, Jinxiu Peng ${ }^{1}$, Ping Zhao ${ }^{1}$, Ranran Zhu ${ }^{1}$, Hailin Wang ${ }^{2}$, \\ Yuan $\mathrm{Li}^{2}$, Kairong Wang ${ }^{1 *}$, Wenjin Yan ${ }^{1^{*}}$ and Rui Wang ${ }^{1 *}$
}

\begin{abstract}
Antimicrobial peptide has the potential to be developed as new kind of antimicrobial agents with novel action mechanism. However, the susceptibility to protease is a drawback for potential peptides to be clinical used. D-amino acid substitution can be one way to increase the proteolytic stability of peptides. In the present study, we synthesized the D-lysines substituted analog (D-lys-MPI) and the D-enantiomer of polybia-MPI (D-MPI) to improve the proteolytic resistance of polybia-MPI. Our results showed that, the stability of its D-amino acid partially substituted analog D-lys-MPI was increased. However, it lost antimicrobial activity at the tested concentration with the loss of a-helix content. As shown in the CD spectra, after substitution, the spectra of D-MPI is symmetrical to MPI, indicated it turned into left hand a-helical conformation. Excitingly, the stability of D-MPI toward the tested protease was improved greatly. Notably, the antimicrobial activity of D-MPI was comparable to its L-counterpart MPI, even improved. In addition, the hemolytic activity of D-MPI was lowered. This also indicated that the action target of antimicrobial peptide polybia-MPI was not chiral specific. So, D-MPI may offer a therapeutic strategy to defend the infection of microbes, considering its stability to protease and relatively lower cytotoxicity to human erythrocytes.
\end{abstract}

Keywords: Antimicrobial peptide, Polybia-MPI, Stability, D-Amino acid substitution

\section{Introduction}

Antimicrobial peptide (AMPs) is a component of innate defense system in most multicellular organisms, from humans to plants to insects. To date more than 2200 natural or synthetic AMPs have been reported through the antimicrobial peptide database (APD) (Silva et al. 2014). Antimicrobial peptides (AMPs) are generally composed of short sequences of 10-100 amino acids residues and highly amphipathic and membrane active (Reddy et al. 2004). AMPs have a broad spectrum of antibacterial, antifungal, antiviral, and anti-tumor activity at low concentrations. Unlike traditional antibiotics, antimicrobial

\footnotetext{
*Correspondence: wangkr@|zu.edu.cn; yanwj@|zu.edu.cn; wangrui@|zu. edu.cn

†Yanyan Zhao and Min Zhang contributed equally to this work

${ }^{1}$ Key Laboratory of Preclinical Study for New Drugs of Gansu Province, School of Basic Medical Sciences, Lanzhou University, 222 Tian Shui South Road, Lanzhou 730000, People's Republic of China

Full list of author information is available at the end of the article
}

peptides can regulate the host immune system and kill bacteria directly (Gottler and Ramamoorthy 2009). Furthermore, other biological activities of AMPs have also been described as following: neutralization of endotoxins, immune-modulating properties, chemokine-like activities, and induction of both angiogenesis and wound repair (Guaní-Guerra et al. 2010).

Although AMPs have broad spectrum of antimicrobial activity, the therapeutic applications of them still have many limitations, such as cytotoxicity, instability and high cost. Many antimicrobial peptides have cytotoxicity to mammalian cells at high concentrations, which may be due to membrane cracking mechanism (Marr et al. 2006). Moreover, AMPs could be degraded or removed by the endogenous protease or secreted by organism before arriving at the action sites. Therefore, their antimicrobial activities were greatly reduced or completely lost (Bowdish et al. 2005; Maisetta et al. 2008). The first commercial AMP was pexiganan acetate (MSI-78) which 
was an $\alpha$-helical magainin variant peptide. MSI-78 has broad spectrum activity for treating foot ulcers and has developed into phase III clinical trials (Kang et al. 2012). BPI is a cationic protein from human neutrophil-derives which has antibacterial activity has just entered phase-III clinical trials (Ge et al. 1999; Hancock and Lehrer 1998). And up to now, no one have obtained US Food and Drug Administration (FDA) approval, except gramicidin for topical administrations (Steckbeck et al. 2014).

Recently, in order to reducing the toxicity and proteolytic degradation, many strategies were developed. It has been reported that the toxicity of AMPs can be reduced by modest sequence modifications (Kim et al. 2014). Strategies used to protect AMPs from protease degradation were mainly including cyclization, incorporation of non-proteinogenic amino acids, and sequence modification such as D-amino acids to replace the $\mathrm{L}$-amino acids (Braunstein et al. 2004; Choi et al. 2013; Hamamoto et al. 2002; Lee and Lee 2008). Furthermore, several studies had reported D-amino acid substitution can improve the activity of AMPs or retain its activity, and more importantly can improve their stability.

Polybia-MPI, was a cationic peptide originally isolated from the venom of the social wasp Polybia paulista (Souza et al. 2005). Its primary sequence is IDWKKLLDAAKQIL-NH2 (1654.09 Da). We have demonstrated that Polybia-MPI displays potent antibacterial activity against both Gram-positive and Gram-negative bacteria. Furthermore, it was also found that polybia-MPI has potent antifungal activity and antitumor activity, and low toxicity to human red blood cells and normal fibroblasts (Wang et al. 2008, 2013). However, it is susceptive to the protease, which limits its clinical application. In the present study, its partial D-amino acid derivative D-lys-MPI (in which all L-lys was substituted by D-lys) and D-enantiomer (D-MPI) were synthesized by solid-phase peptide synthesis. Then their antimicrobial activity, hemolytic activity and stability were determined. Furthermore, the effect of such modification on the bioactivity, secondary structure and action mechanism was discussed.

\section{Materials and methods}

\section{Synthesis of peptide}

Polybia-MPI(I-D-W-K-K-L-L-D-A-A-K-Q-I-L-NH2 $(1654.09 \mathrm{Da})$ and its analogues were synthesized by the standard Fmoc solid-phase peptide synthesis (Fields and Noble 1990; Wang et al. 2008). Each of synthesized peptide was purified to over $95 \%$ by reversed-phase high performance liquid chromatography (RP-HPLC) using a $\mu$ Bondapak C18 19- by $300-\mathrm{mm}$ column. The flow rate was $8 \mathrm{ml} / \mathrm{min}$ and the gradient used was $5-95 \%$ solvent $(\mathrm{CH} 3 \mathrm{CN} / \mathrm{H} 2 \mathrm{O}$ with $0.1 \%$ trifluoroacetic acid) over 60 min (Yan et al. 2012). The molecular weights were verified by matrix-assisted laser desorption ionizationtime-of-flight mass spectrometry (ESI-MS). All the peptides were dissolved in deionized water and diluted by PBS before use.

\section{Antimicrobial assays}

The minimal inhibitory concentration (MIC) of the peptides was measured in triplicate by the standard broth microdilution method (Peterson et al. 1980; Wang et al. 2012). In brief, bacteria/fungi were cultured overnight to mid-logarithmic-phase in Mueller-Hinton broth (MHB)/ Sabouraud dextrose broth. The cultures were diluted to a final concentration of $2 \times 10^{4} \mathrm{cfu} / \mathrm{ml}$ in fresh MuellerHinton broth (MHB)/Sabouraud dextrose broth. Each well of 96-well propylene microtitre plates was filled with $100 \mu \mathrm{l}$ cell suspension and $100 \mu \mathrm{l}$ peptide solution of twofold diluted serially. And the final concentrations of peptide mixtures ranged from 1 to $256 \mu \mathrm{M}$. Controls were done without peptides. After $18 \mathrm{~h}$ of incubation at $37^{\circ} \mathrm{C}$ (bacteria) $/ 35{ }^{\circ} \mathrm{C}$ (fungi), the minimal inhibitory concentration (MIC) of the peptides was evaluated by visible turbidity in each well.

The minimal bactericidal concentrations (MBCs) and minimum fungicidal concentration (MFCs) of the peptides was determined at the end of the incubation period by transferring $50 \mu \mathrm{l}$ aliquots onto agar plates and incubated overnight at $37{ }^{\circ} \mathrm{C} / 35^{\circ} \mathrm{C}$. The $\mathrm{MBC} / \mathrm{MFC}$ was set as the lowest concentration of the number of CFUs that reduced at least $99.9 \%$.

\section{Time-kill analysis}

Strains was grown overnight with shaking to mid-logarithmic phases described above (Wang et al. 2015). The cultures containing $10^{4}-10^{5} \mathrm{CFU} / \mathrm{ml}$ was incubated with different concentration of peptides which determined by MIC assay via the broth microdilution method. A nopeptide (control) tube was also included in each run. The cultures were incubated in a $37{ }^{\circ} \mathrm{C} / 35^{\circ} \mathrm{C}$. shaking incubator. At different time intervals over the incubation period, samples from each tube were removed respectively and serially (tenfold) diluted, and $100 \mu \mathrm{l}$ of the dilution were plated on agar plates. Plates were incubated at $37{ }^{\circ} \mathrm{C} / 35^{\circ} \mathrm{C}$ and determine the numbers of $\mathrm{CFU}$ after $24 \mathrm{~h}$.

\section{Hemolytic activity}

Fresh human blood was collected in heparinized-tube, diluted in cold PBS ( $\mathrm{pH} 7.4$ ) and centrifuged at $800 \mathrm{~g}$ for $10 \mathrm{~min}$ to remove the serum and buffy coat. The erythrocytes were washed twice time and re-suspended in the same buffer to a final erythrocyte concentration of $8 \%$ for the hemolysis assay (Sharma and Sharma 2001). The RBC (red blood cell) suspension of $100 \mu \mathrm{l}$ was transferred into 
a 96 well microtiter plate. Peptides were dissolved in PBS (pH 7.4) of different concentrations from 2 to $256 \mu \mathrm{M}$ were incubated with $8 \%$ erythrocytes suspension for $60 \mathrm{~min}$ at $37^{\circ} \mathrm{C}$. Subsequently, the plate was centrifuged at $1200 \times \mathrm{g}$ for $10 \mathrm{~min}$. Then, aliquots of $100 \mu \mathrm{l}$ supernatant were retransferred to an another 96-well plates and measured to monitor the release of hemoglobin by microplate reader (Bio-Rad 680) at $490 \mathrm{~nm}$, which indicated RBC membrane damage. $100 \mu \mathrm{l}$ RBC (red blood cell) suspension with $0.2 \%$ Triton-X 100 or PBS was used as positive and negative control, respectively. Hemolysis rate was determined as below:

$$
\begin{aligned}
& \text { Hemolysis rate }(\%) \\
& \quad=(\mathrm{A}-\mathrm{A} 2) /(\mathrm{A} 1-\mathrm{A} 2) \times 100 \%
\end{aligned}
$$

where $\mathrm{A}$ is the absorbance of indicator mixtures with different factors, A1 and A2 are the positive control, and the negative control, respectively (Kim et al. 2011).

\section{Circular dichroism spectroscopy analysis}

The circular dichroism (CD) spectra of peptides were measured on an Olis DSM 1000 CD spectrophotometer (USA) in spectra between 195 and $240 \mathrm{~nm}$ under nitrogen flush in $1 \mathrm{~mm}$ path length at room temperature. The scanning speed was $100 \mathrm{~nm} / \mathrm{min}, 2 \mathrm{~s}$ response time and $1.0 \mathrm{~nm}$ spectral band width. The measurements were performed with a peptide concentration of $50 \mathrm{mM}$. The spectra were measured in 50\% TFE (v/v) and $10 \mathrm{mM}$ PBS (pH 7.4), and the average of four scans was taken.

\section{Assessment of stability Viability assay}

Viability assay different concentration of trypsin (from 0.0002 to $2 \mathrm{mg} / \mathrm{ml}$ ) incubated with peptides for 1 or $6 \mathrm{~h}$ at $37{ }^{\circ} \mathrm{C}$, and the enzymatic activity was terminated by additional heat inactivation at $60{ }^{\circ} \mathrm{C}$ for $20 \mathrm{~min}$. Then the trypsin treated peptides were incubated with Escherichia coli (ATCC25922) at the concentration of MIC in 96-wells microtiter plate overnight at $37{ }^{\circ} \mathrm{C}$ (Choi et al. 2013). The growth inhibitory effect was determined by measuring the absorbance at $600 \mathrm{~nm}$. Then we took $100 \mu \mathrm{l}$ samples of $6 \mathrm{~h}$ from each well with the concentration of $0.2 \mathrm{mg} / \mathrm{ml}$ and plated onto $\mathrm{MH}$ broth ager after dilution. After overnight incubation at $37{ }^{\circ} \mathrm{C}$, photos of plates were photographed and the colonies on the plate were counted.

\section{Radial diffusion assay}

The enzymatic stability of Polybia-MPI and its analogues was evaluated by a modification of the sensitive radial diffusion assay. The bacteria were cultured until the optical density at $600 \mathrm{~nm}$ (OD600) of an aliquot reached 0.5. One milliliter of the bacteria suspension was added to $100 \mathrm{ml}$ of previously autoclaved, warm Mueller-Hinton agar (MHA)/ Sabouraud dextrose agar. The medium were poured into layer of a $5 \mathrm{~mm}$ deep. Wells were performed with a sterile plastic bore of a 3-mm-diameter gel punch. Following the addition of $20 \mu \mathrm{l}$ pre-incubated mixture of peptides and different concentrations of trypsin or chymotrypsin for

Table 1 MIC values of polybia-MPI, D-MPI and D-lys-MPI against the tested Bacteria cells and Candida cells

\begin{tabular}{lccc}
\hline Organism & \multicolumn{1}{l}{ MIC $(\boldsymbol{\mu M})$} & \\
\cline { 2 - 4 } & Polybia-MPI & D-MPI & D-lys-MPI \\
\hline Bacteria & 32 & 16 & $>256$ \\
E. coli (ATCC 2592) & 32 & 32 & $>256$ \\
E. coli (ML-35) (ATCC 43827) & 64 & 64 & $>256$ \\
Klebsiella influenza (ATCC 700603) & 128 & 64 & $>256$ \\
Pseudomonas aeruginosa (ATCC & & & \\
$\quad$ 27853) & 64 & 32 & $>256$ \\
sakazakii (ATCC 29544) & 32 & 16 & $>256$ \\
Staphylococcus aureus (ATCC 29213) & 3 & 8 & $>256$ \\
Bacillus subtilis (ATCC 23857) & 82 & 16 & 256 \\
Staphylococcus epidermidis (ATCC & 32 & & \\
$\quad$ 12228) & & & \\
Fungi & 8 & 16 & 128 \\
Candida glabrata ATCC (ATCC 2001) & 856 \\
Candida albicans ATCC (ATCC 14053) & 16 & 16 & 256 \\
Candida parapsilosis (ATCC 22019) & 64 & 32 & $>256$ \\
Candida tropicalis (ATCC 750) & 8 & 16 & 64 \\
Candida krusei (ATCC 6258) & 8 & 8 & 128 \\
\hline
\end{tabular}

Table 2 MBC/MFC values of polybia-MPI, D-MPI and D-lysMPI against the tested Bacteria cells and Candida cells

\begin{tabular}{lccc}
\hline Organism & \multicolumn{3}{l}{ MBC/MFC $(\mu \mathrm{M})$} \\
\cline { 2 - 4 } & Polybia-MPI & D-MPI & D-lys-MPI \\
\hline Bacteria & 32 & 16 & $>256$ \\
E. coli (ATCC2592) & 256 & 64 & $>256$ \\
E. coli (ML-35) (ATCC43827) & 256 & 128 & $>256$ \\
Klebsiella influenza (ATCC 700603) & $>256$ & 128 & $>256$ \\
Pseudomonas aeruginosa & & & \\
$\quad$ ATCC27853) & 64 & 64 & $>256$ \\
sakazakii (ATCC 29544) & 128 & 64 & $>256$ \\
Staphylococcus aureus (ATCC29213) & 8 & 8 & $>256$ \\
Bacillus subtilis (ATCC23857) & 32 & 128 & $>256$ \\
Staphylococcus epidermidis (ATCC & & & \\
$\quad$ 12228) & & & \\
Fungi & 32 & 32 & 256 \\
C. glabrata (ATCC 2001) & 16 & 16 & $>256$ \\
C. albicans (ATCC 14053) & 128 & 32 & $>256$ \\
C. parapsilosis (ATCC 22019) & 32 & 16 & 128 \\
C.tropicalis (ATCC 750) & 16 & 8 & 256 \\
C. krusei (ATCC 6258) & & &
\end{tabular}



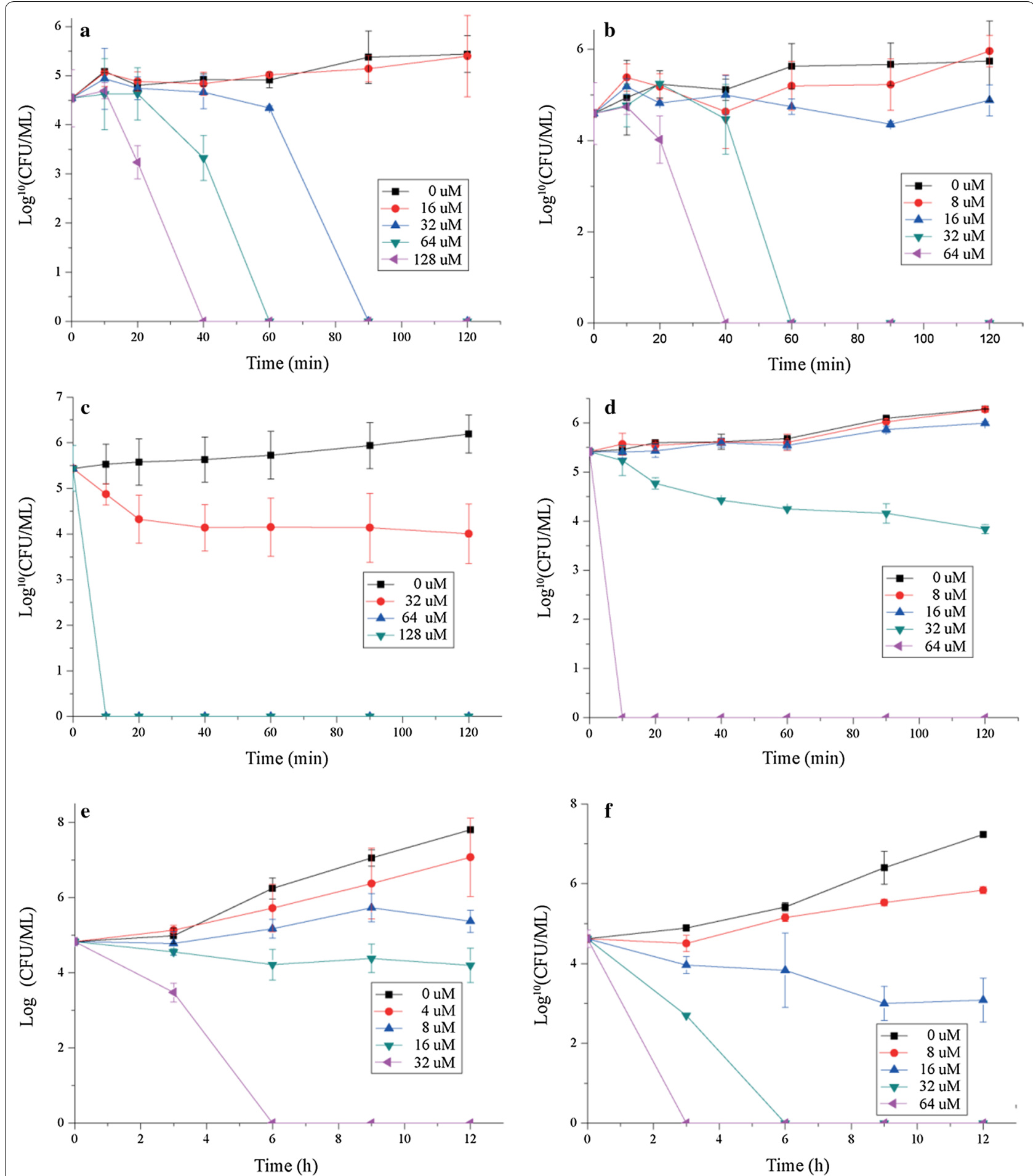

Fig. 1 Time-killing kinetics curves for polybia-MPI and D-MPI against E. coli (a and $\mathbf{b})$, S. aureus (c and $\mathbf{d})$ and C. glabrata (e and f). Standardized cells suspensions were incubated with a final concentration of peptides of $1 / 2 \times M I C, 1 \times M I C, 2 \times M I C, 4 \times M I C$. At different time intervals, samples were taken respectively from each tube and serially diluted. Then $100 \mu \mathrm{l}$ of the dilution were plated for colony counts. Controls were without peptide. Each data point represents mean result \pm standard deviation (error bars) 


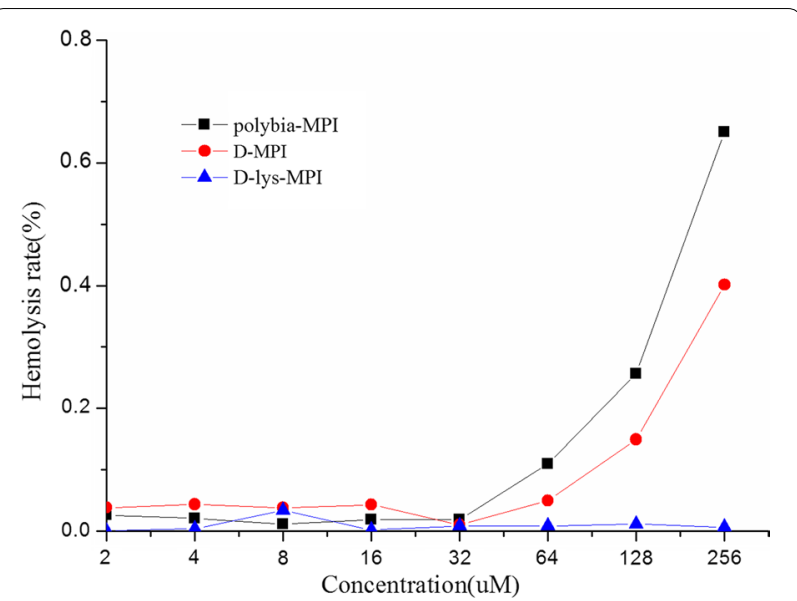

Fig. 2 The hemolytic activity of polybia-MPI and synthetic D-MPI and D-lys-MPI against human erythrocytes were determined. Fresh human blood was collected and centrifuged to remove the serum and buffy coat, and re-suspended to a final erythrocyte concentration of $8 \%$ erythrocytes suspension. Then, peptides of different concentrations from 2 to $256 \mu \mathrm{M}$ were incubated with erythrocytes suspension for $60 \mathrm{~min}$. Subsequently, the erythrocytes suspension was centrifuged and measured to monitor the release of hemoglobin at $490 \mathrm{~nm}$

$4 \mathrm{~h}$ into wells. The plates were incubated at $37^{\circ} \mathrm{C}$ for 18 to $24 \mathrm{~h}$. An equal volume of $20 \mu \mathrm{l}$ mixture had no trypsin or chymotrypsin was used as the control. The size of the clear zones surrounding each well as indicators of the enzymatic stability of Polybia-MPI and its analogues.

\section{RP-HPLC analysis}

The stability of polybia-MPI and its analogues was assayed with trypsin or chymotrypsin in a volume ratio of
1:15 (peptide:trypsin) (Choi et al. 2013; Hamamoto et al. 2002; Molhoek et al. 2011). Peptides at the concentration of $10 \mathrm{mM}$ were incubated with trypsin or chymotrypsin $(0.2 \mathrm{mg} / \mathrm{ml})$ at $37{ }^{\circ} \mathrm{C} .40 \mu \mathrm{l}$ samples of the incubations were taken for the time of 0 and $360 \mathrm{~min}$, respectively. Then, the samples were mixed with $80 \mu \mathrm{l}$ of $15 \%$ trifluoroacetic acid (TFA) and $80 \mu \mathrm{l}$ acetonitrile which incubated at $4{ }^{\circ} \mathrm{C}$ for at least $15 \mathrm{~min}$ to precipitate proteins. The supernatant was collected of each sample after centrifugation at $13,000 \mathrm{rpm}$ for $10 \mathrm{~min}$ and were detected with reverse phase high performance liquid chromatography (RP-HPLC) analysis.

\section{Confocal laser scanning microscopy}

Candida glabrata cells were cultured overnight to midlogarithmic-phase in Sabouraud dextrose broth. After centrifugation and suspension, the cells were incubated with polybia-MPI and its analogues at final concentration of $5 \times$ MIC for $2 \mathrm{~h}$ at room temperature. Then, PI $(50 \mu \mathrm{g} /$ $\mathrm{ml}$ ) was added and was further incubated for $5 \mathrm{~min}$ in the dark (Wang et al. 2012).

\section{Results}

\section{Antibacterial and bactericidal activity}

The antimicrobial activity of D-lys-MPI and D-MPI against bacteria and fungi were determined. As shown in Table 1, D-MPI could potently inhibit the growth of all tested bacterial and fungal strains with MIC values almost in the range of $8-64 \mu \mathrm{M}$. However, D-lys-MPI was inactive against bacteria and much less active against fungal strains at the tested concentration. Compared with polybia-MPI, the inhibitory effects of D-MPI was
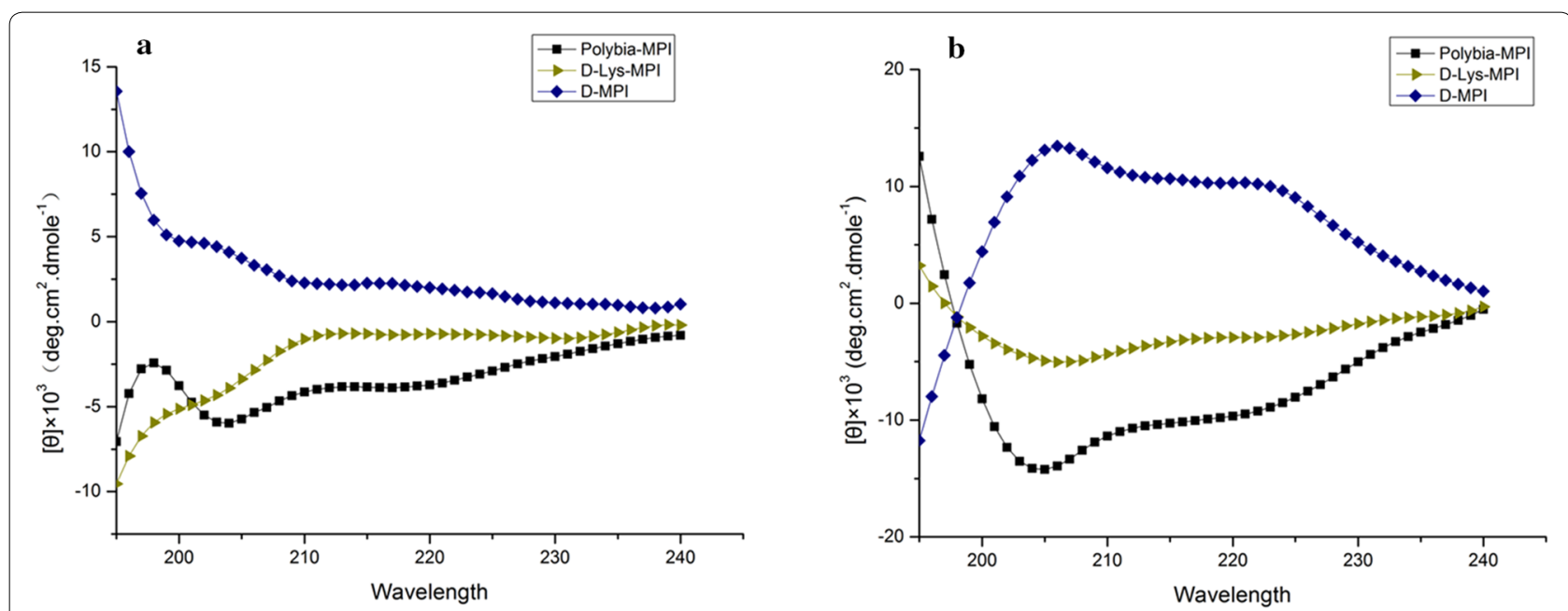

Fig. 3 Circular dichroism spectra analysis of polybia-MPI and its analogues. a sodium phosphate buffer. b Membrane-mimicking environment (50\% TFE) 
improved more or less, which also could be seen in the bactericidal or fungicidal activity (Table 2). As shown in Fig. 1, the improvement of bactericidal or fungicidal activity also could be reflected in the time-killing curves of D-MPI against the tested strains.

\section{Hemolytic activity}

The hemolytic activity of polybia-MPI, D-lys-MPI and D-MPI against human erythrocytes was determined with the concentration ranging from 1 to $256 \mu \mathrm{M}$. As indicated in Fig. 2, no significant hemolytic activity was found under the concentration of $100 \mu \mathrm{M}$. Compared to its L-counterpart polybia-MPI, the hemolytic activity of D-MPI was decreased after the D-amino acid substitution. After substitution of L-lysine by D-lysine in the peptide sequence, the hemolytic activity also was abrogated.

\section{Circular dichroism spectroscopy analysis}

The secondary structure of these peptides were determined in $10 \mathrm{mM}$ sodiumphosphate buffer (PBS, pH 7.4) and a membrane-mimicking environment (50\% 2,2,2-trifluoroethanol) by circular dichroism spectroscopy. As shown in Fig. 3, all the peptides displayed a unordered structure in PBS. In the membrane-mimicking environment, D-MPI showed a negative band at $195 \mathrm{~nm}$, and two positive bands near 208 and $222 \mathrm{~nm}$, which was mirror symmetrical to its L-counterpart polybia-MPI. D-MPI takes a left hand $\alpha$-helical conformation in the membrane-mimicking environment. However, the D-lysMPI showed a decreased $\alpha$-helical conformation after the substitution of L-lysine with D-lysine for there is a quite slightly tendency of negative bands around 208 and $222 \mathrm{~nm}$.

\section{Stability of the peptides Viability assay}

One of the major limitation of AMPs for clinical use is that AMPs could be easily degraded by the endogenous proteases. To test the stability of polybia-MPI and D-MPI, first $1 \mathrm{mg} / \mathrm{l}$ of the peptides were incubated with trypsin and chymotrypsin for $4 \mathrm{~h}$ for degradation. After the enzyme was heat inactivated at $60^{\circ} \mathrm{C}$ for $15 \mathrm{~min}, E$. coli was added and co-incubated for $3 \mathrm{~h}$. Then, the treated bacteria were coated to plate and incubated at $37{ }^{\circ} \mathrm{C}$ for $24 \mathrm{~h}$. As shown in Fig. 4, there are no colony grown on the trypsin-D-MPI-treated plate, while there are many colonies grown on the trypsin-MPI-treated plate. D-MPI showed significant protease resistance against trypsin. To further examine the susceptibility of peptides to protease, peptides was incubated with the different concentration of trypsin ( $a$ and $b$ ) and chymotrypsin (c and d) (ranged

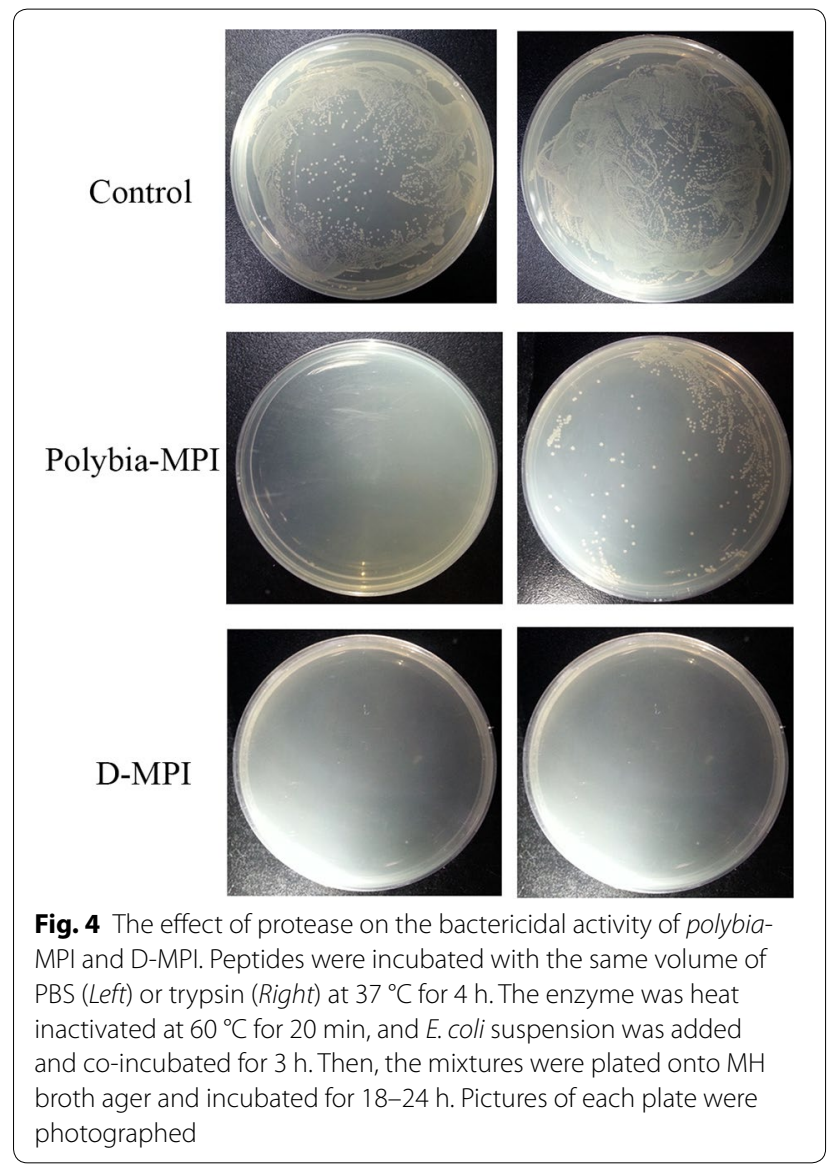

from 0.0002 to $2 \mathrm{mg} / \mathrm{ml}$ ) for 1 and $6 \mathrm{~h}$ respectively, then the relative survival rate of $E$. coli were determined. As shown in Fig. 5, trypsin and chymotrypsin could totally inhibit the antimicrobial activity of polybia-MPI at the concentration of $0.002 \mathrm{mg} / \mathrm{ml}$ after incubation $1 \mathrm{~h}$, while D-MPI retained its antimicrobial activity after incubation with $2 \mathrm{mg} / \mathrm{ml}$ of trypsin and chymotrypsin for $6 \mathrm{~h}$. This result was further confirmed by radical diffusion assay. As shown in Fig. 6, the inhibition zone diameters in polybia-MPI treated group were decreased even disappeared after incubation with $0.02-2 \mathrm{mg} / \mathrm{ml}$ of trypsin and chymotrypsin, respectively. However, in the D-MPI treated group the inhibition zone diameters was almost the same as control after the incubation with $2 \mathrm{mg} / \mathrm{ml}$ of tested proteases.

\section{RP-HPLC analysis}

In the present study, HPLC was used to determine the stability of polybia-MPI, D-lys-MPI and D-MPI to trypsin, chymotrypsin and proteases in human serum. When comparing the HPLC profile of untreated peptides 


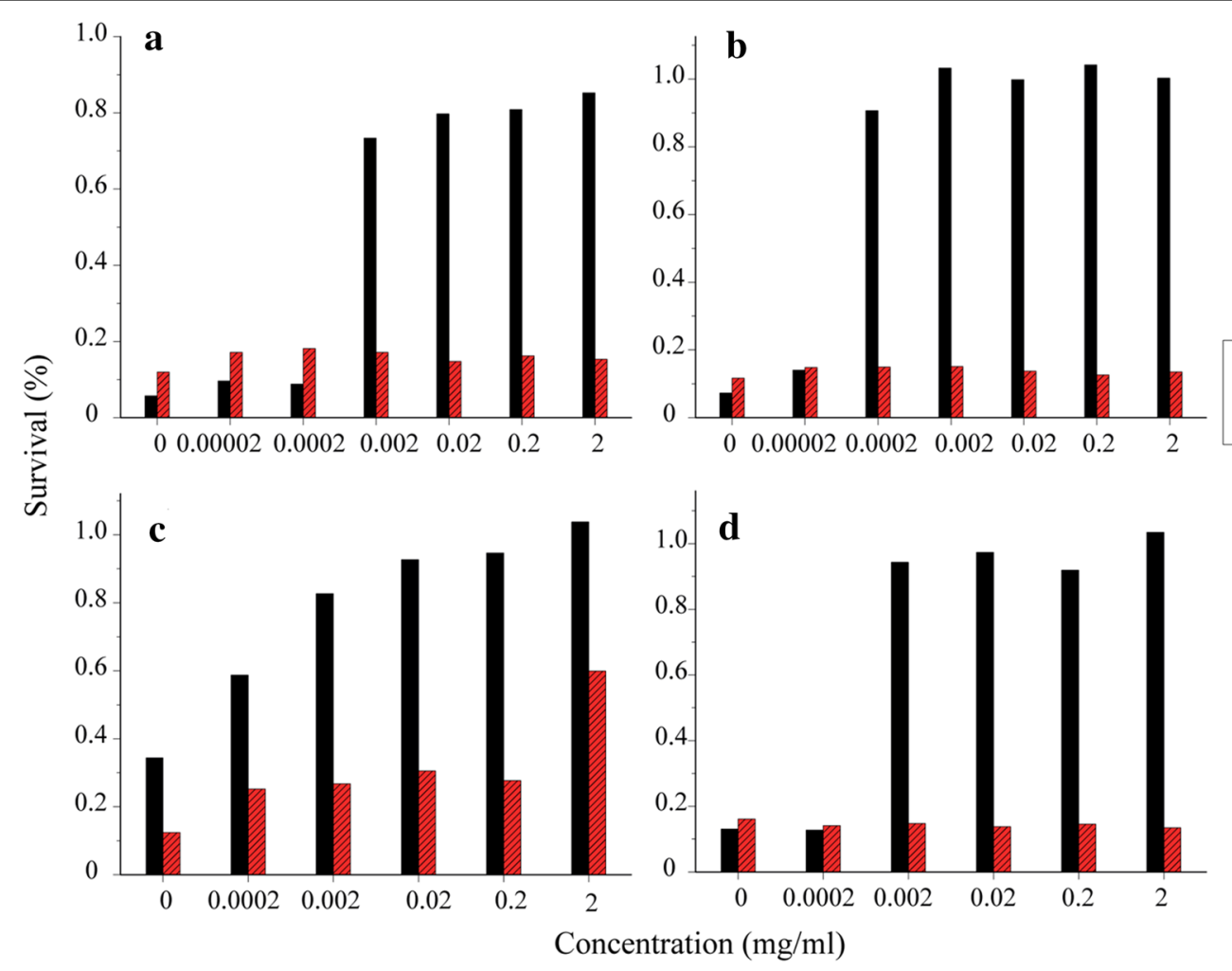

Fig. 5 Inhibition effect of protease on the antimicrobial activity of polybia-MPI and D-MPI. The proteases used were trypsin (a and $\mathbf{b})$ and chymotrypsin (c and $\mathbf{d}$ ). Peptides with proteases of different concentration which ranged from 0.0002 to $2 \mathrm{mg} / \mathrm{ml}$ (tenfold) were incubated for $1 \mathrm{~h}$ (left) or $6 \mathrm{~h}$ (right) at $37^{\circ} \mathrm{C}$, respectively. Then tested for its antimicrobial activity against $E$. coli by determine the OD values at $600 \mathrm{~nm}$

to the HPLC profile of trypsin and chymotrypsin treated peptides, it was found that polybia-MPI was susceptible to all the tested enzymes and serum, while its partially D-lysine substituted analogue and fully D-amino acid substituted were not or only partly degraded after treatment (Fig. 7).

\section{Peptides induced cell membrane permeabilization}

To determine the effect of D-MPI on the integrity of the fungal cell membrane, PI uptake assay was employed in the present study. PI was a kind of DNA intercalating fluorescent dye, which could only pass through the damaged cell membranes and combined with DNA to form a PI-DNA complex. As shown in Fig. 8, there is no fluorescence in the control group $(\mathrm{A}-\mathrm{C})$, while the $\mathrm{D}$-MPI treated group (G-I) showed fluorescence as its L-counterpart treat group (D-F), indicating that D-MPI also could disrupt the integrity of the cell membrane.

\section{Discussion}

Since the golden age of antibiotics, antibiotics had truly become the "panacea" in the field of medicine and were being used to treat even the most common infections. However, spawned a series of multi-drug resistant bacteria with the indiscriminate use and abuse of antibiotics,traditional antibiotics have been unable to meet the needs of clinical medicine (Wang et al. 2016). Therefore, the urgent need for new antibiotics has stimulated the rapid development of antimicrobial peptides. Most antimicrobial peptides are presented with a positive charge at neutral $\mathrm{PH}$ and have an amphiphilic topology, so they can combined with a negatively charged phospholipid head, and ultimately damage membrane structure through interactions with cytoplasmic membrane (Wang et al. 2013). Due to these special properties, antimicrobial peptides are therefore considered to be a potential alternative to traditional antibiotics. Although 


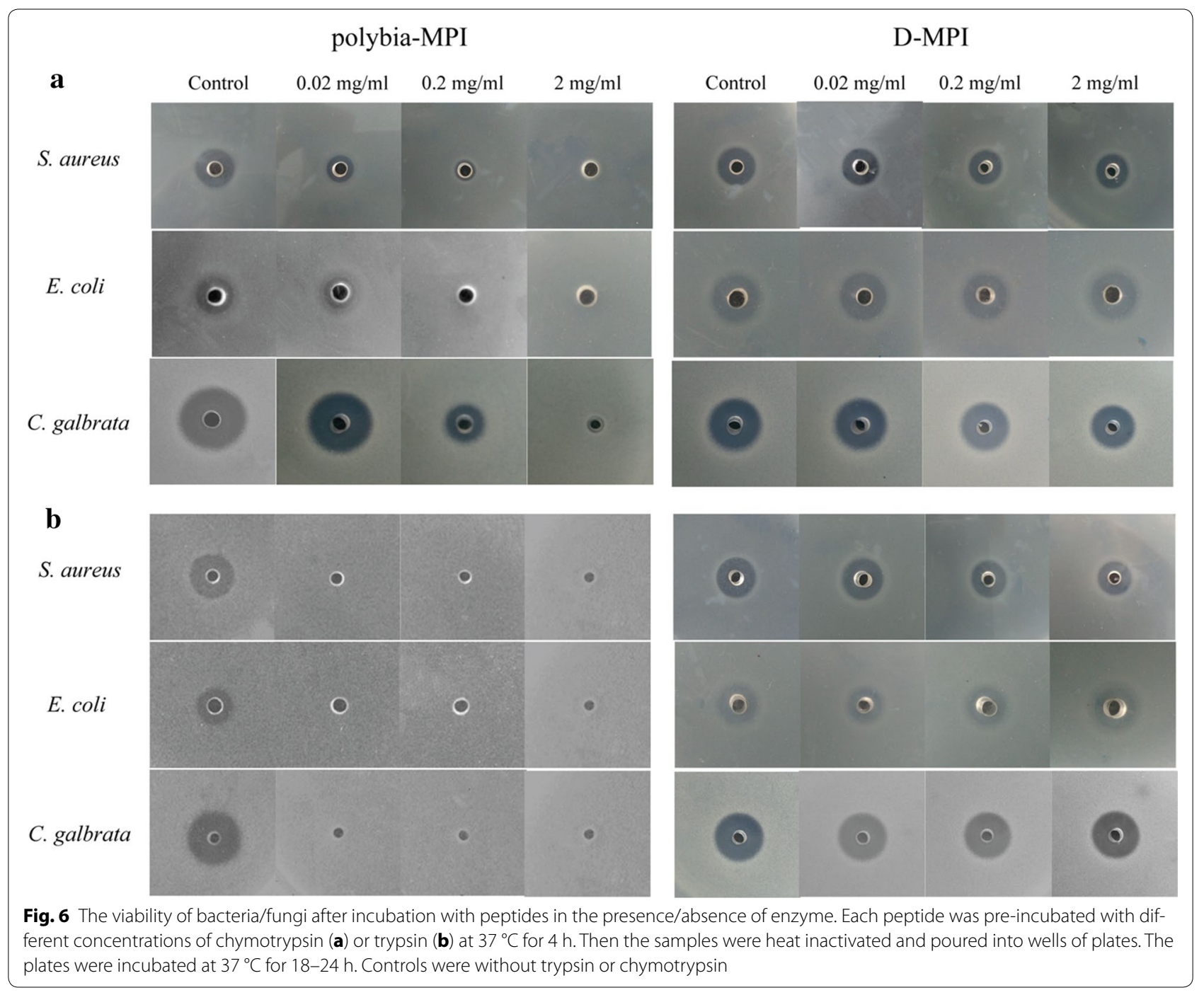

AMPs have broad spectrum antimicrobial activity in vitro, there are many obstacles in clinical application, such as cell toxicity, instability and high cost (Kim et al. 2014). To solve these problems, many methods have been reported. For instance, substitution Trp and Phe residues with less hydrophobic amino acids can decreases the toxicity of AMPs (Kim et al. 2014). Introduction of nonnatural amino acids (mainly D-form amino acids), cyclization or modification the terminal regions by acetylation or amidation can improve the stability of peptides (Wei and Bobek 2005; Kim et al. 2014).

In nature, almost all of the proteins and peptides were composed of L-amino acid. Different enzyme could recognize specific peptide bond formed by L-amino acid and break it (Chen et al. 2016). However, enzyme could not break the peptide bond formed by D-amino acid for the difference of the spatial configuration. Actually, there is no difference between $\mathrm{L}$-amino acid and its $\mathrm{D}$-counterpart in the chemical and physical property. So, D-amino acid substitution almost has no influence on the chemical and physical property of the peptides except the configuration. As the influence of $\mathrm{D}$-amino acid substitution on the biological activity of peptides, it is depend on that if the action mechanism related to the recognition of chiral targets (Braunstein et al. 2004). In the present study, when only the three Lysines in the sequence of polybia-MPI were substituted by their D-counterparts, the secondary structure was changed compared to 


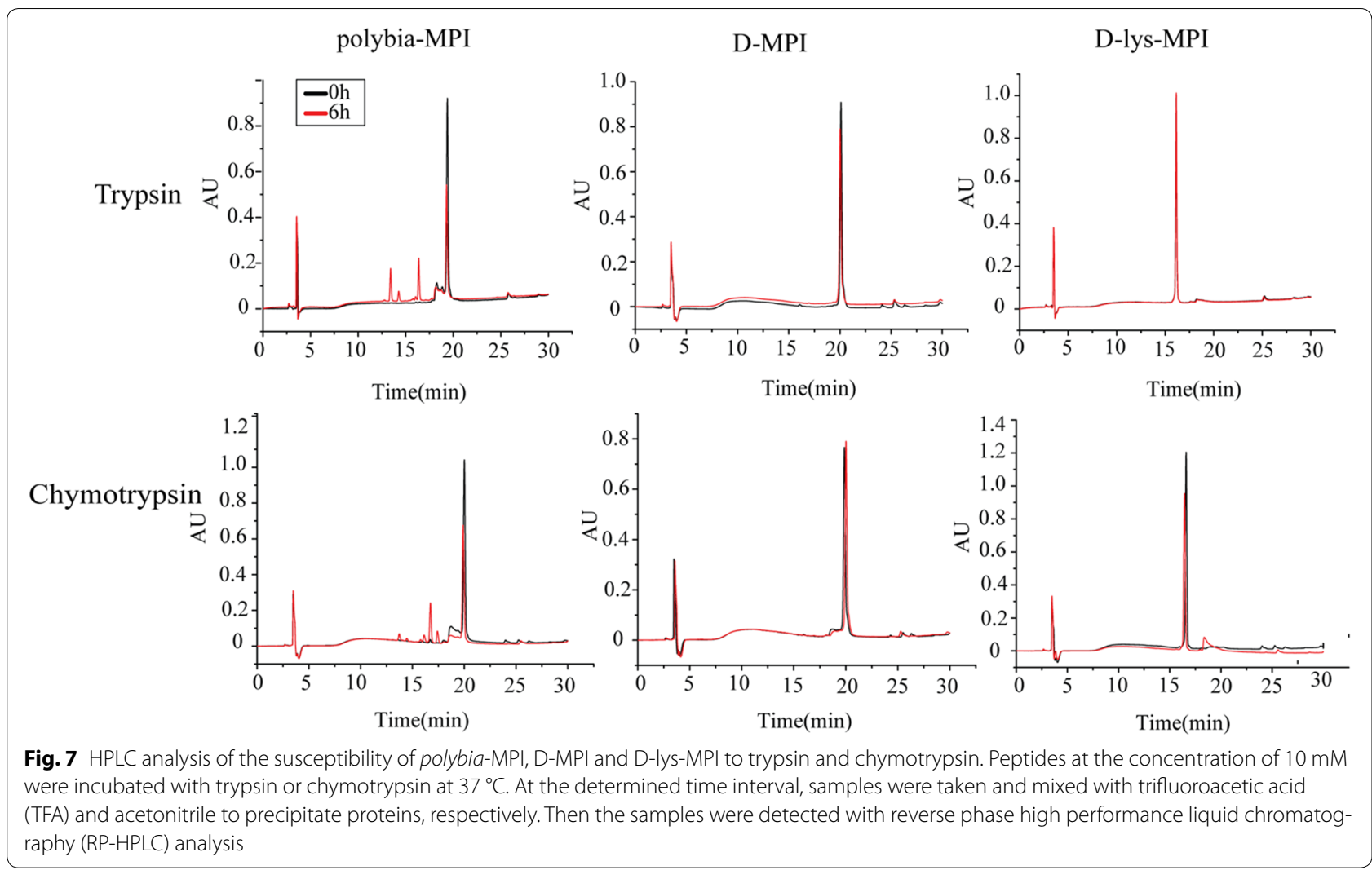

polybia-MPI and the peptide almost lost all the biological activity in the tested concentration. However, when all the L-amino acids in the sequence of polybia-MPI were substituted by $\mathrm{D}$-amino acids, the configuration was reversed. The D-enantiomer of polybia-MPI was turned into left hand $\alpha$-helical conformation. More importantly, all D-amino acid substitution didn't affect its biological activity. D-MPI has the same antimicrobial activity even improved activity as polybia-MPI.

Furthermore, the action mechanism of D-MPI also was analyzed in the present study. The action mode of AMPs has been investigated in many studies. Many AMPs were found that they could bind with the membrane of microbes and then disrupt the integrity of cell membrane (Arnusch et al. 2012). There are mainly three models, the barrel-stave model, the toroidal pores model, and the carpet model (Chih et al. 2015), which are widely accepted to describe the membrane-active action mode. Membrane active action mode of AMPs was believed that it is difficult for microbes to develop resistance toward AMPs (Hancock and Sahl 2006). The L-counterpart of D-MPI mainly exerts its antitumor, antibacterial and antifungal activity through the disruption of the integrity of cell membrane (Wang et al. 2008, 2009, 2013, 2014). As expected, it may also exert its antimicrobial activity through disrupting the integrity of cell membrane and lead to the death of cells. This kind of cell membrane lysis action mechanism always was not dependent on the chiral recognition, which support that D-MPI retained the activity of its L-counterpart. Interestingly, all D-amino acid substitution also decreased the hemolytic activity of polybia-MPI.

In conclusion, our results showed that the fully substitution of all the amino acid of polybia-MPI with D-amino acid could protect the peptide from the degradation of the tested proteases. This modification turned right hand $\alpha$-helical conformation of polybia-MPI to left hand conformation and retained or improved the antimicrobial activity of polybia-MPI. Although the partially D-lysine substitution could improve the stability of polybia-MPI toward the tested protease, the secondary conformation was changed after modification and its antimicrobial activity decreased greatly. So, D-MPI 


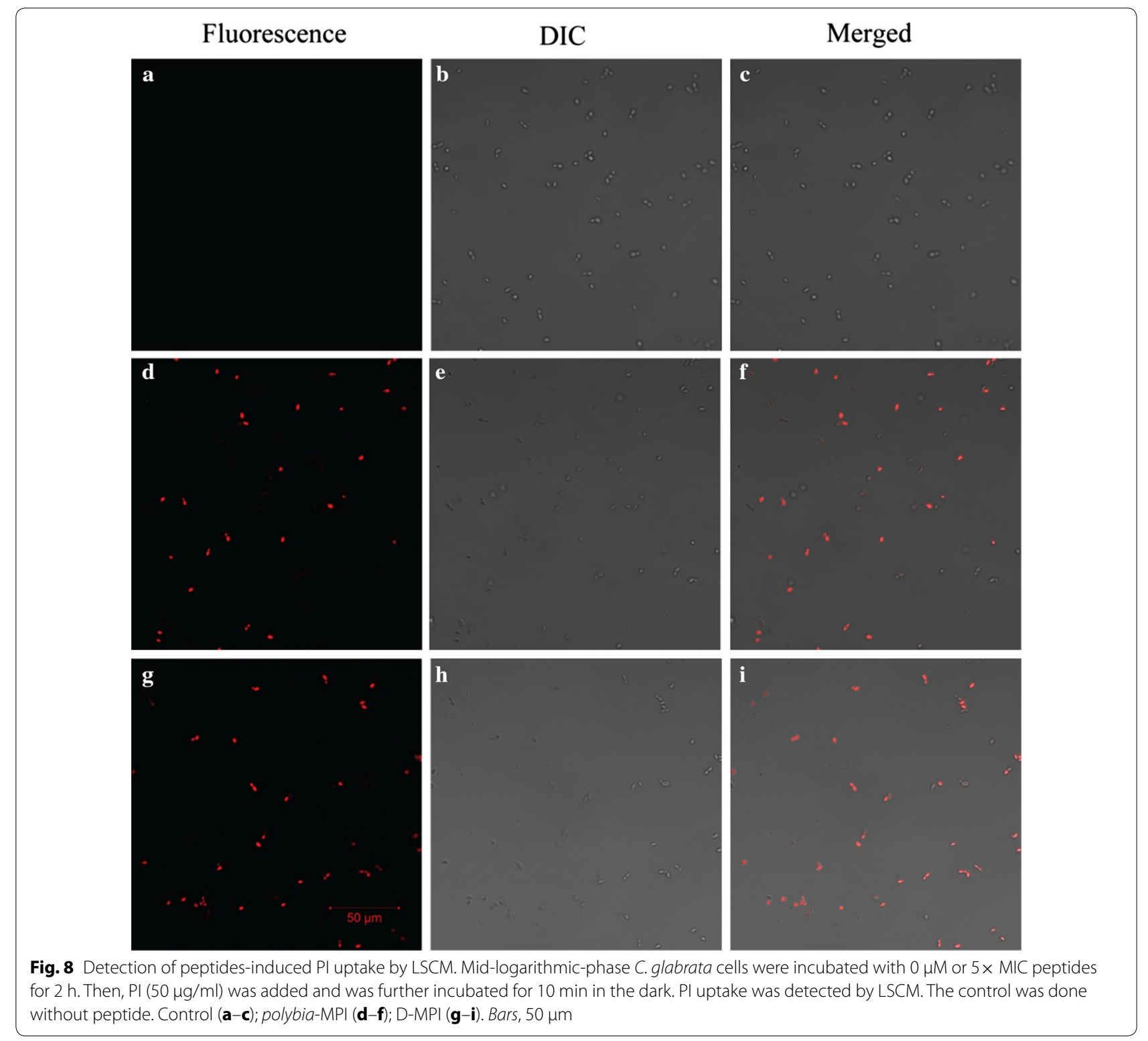

may offer a new strategy and will be an excellent alternative to conventional antibiotics to defend the resistant bacteria.

\section{Authors' contributions}

$Y Z, M Z, S Q, J W, J P, P Z, R Z$ carried out the experiments. KW, WY, RW, HW and YL participated in the design of the study, and supervised the research work. $Y Z$ and KW drafted the original manuscript. MZ, HW, YL, WY and RW helped to review and editing the manuscript. WY and RW take part in the project administration and funding acquisition. MZ, HW, YL, KW, WY and RW participated in the providing the necessary resources and funding acquisition. All authors read and approved the final manuscript.

\section{Author details}

${ }^{1}$ Key Laboratory of Preclinical Study for New Drugs of Gansu Province, School of Basic Medical Sciences, Lanzhou University, 222 Tian Shui South Road,
Lanzhou 730000, People's Republic of China. ${ }^{2}$ The People's Hospital in Gansu Province, 204 West Donggang Road, Lanzhou 730000, People's Republic of China.

\section{Acknowledgements}

This work was supported by grants from the National Natural Science Foundation of China (Nos. 81573265, 91213302, 21272108, 81473095, $81260387,81360112)$; the Natural Science Foundation of Gansu Province, China (1208RJZ109, 1606RJA159) and the Fundamental Research Funds for the Central Universities (Izujbky-2015-279, Izujbky-2015-k11 and Izujbky-2016-ct01).

\section{Competing interests}

The authors declare that they have no competing interests.

Received: 9 November 2016 Accepted: 22 November 2016 Published online: 29 November 2016 


\section{References}

Arnusch CJ, Ulm H, Josten M, Shadkchan Y, Osherov N, Sahl HG, Shai Y (2012) Ultrashort peptide bioconjugates are exclusively antifungal agents and synergize with cyclodextrin and amphotericin b. Antimicrob Agents Chemother 56(1):1-9

Bowdish DM, Davidson DJ, Hancock RE (2005) A re-evaluation of the role of host defence peptides in mammalian immunity. Curr Protein Pept Sci 6(1):35-51

Braunstein A, Papo N, Shai Y (2004) In vitro activity and potency of an intravenously injected antimicrobial peptide and itS DL amino acid analog in mice infected with bacteria. Antimicrob Agents Chemother 48(8):3127-3129

Chen HL, Su PY, Shih C (2016) Improvement of in vivo antimicrobial activity of hbcard peptides by D-arginine replacement. Appl Microbiol Biotechnol 100(21):9125-9132

Chih YH, Lin YS, Yip BS, Wei HJ, Chu HL, Yu HY, Cheng HT, Chou YT, Cheng JW (2015) Ultrashort antimicrobial peptides with antiendotoxin properties. Antimicrob Agents Chemother 59(8):5052-5056

Choi H, Hwang JS, Kim H, Lee DG (2013) Antifungal effect of CopA3 monomer peptide via membrane-active mechanism and stability to proteolysis of enantiomeric D-CopA3. Biochem Biophys Res Commun 440(1):94-98

Fields GB, Noble RL (1990) Solid phase peptide synthesis utilizing 9-fluorenylmethoxycarbonyl amino acids. Int J Pept Protein Res 35(3):161-214

Ge Y, MacDonald D, Henry MM, Hait HI, Nelson KA, Lipsky BA, Zasloff MA Holroyd KJ (1999) In vitro susceptibility to pexiganan of bacteria isolated from infected diabetic foot ulcers. Diagn Microbiol Infect Dis 35(1):45-53

Gottler LM, Ramamoorthy A (2009) Structure, membrane orientation, mechanism, and function of pexiganan-A highly potent antimicrobial peptide designed from magainin. Biochimica Et Biophysica Acta-Biomembranes 1788(8):1680-1686

Guaní-Guerra E, Santos-Mendoza T, Lugo-Reyes SO, Terán LM (2010) Antimicrobial peptides: general overview and clinical implications in human health and disease. Clin Immunol 135(1):1-11

Hamamoto K, Kida Y, Zhang Y, Shimizu T, Kuwano K (2002) Antimicrobial activity and stability to proteolysis of small linear cationic peptides with D-amino acid substitutions. Microbiol Immunol 46(11):741-749

Hancock RE, Lehrer R (1998) Cationic peptides: a new source of antibiotics. Trends Biotechnol 16(2):82-88

Hancock REW, Sahl HG (2006) Antimicrobial and host-defense peptides as new anti-infective therapeutic strategies. Nat Biotechnol 24:1551-1557

Kang SJ, Kim DH, Mishig-Ochir T, Lee BJ (2012) Antimicrobial peptides: their physicochemical properties and therapeutic application. Arch Pharmacal Res 35(3):409-413

Kim JK, Lee E, Shin S, Jeong KW, Lee JY, Bae SY, Kim SH, Lee J, Kim SR, Lee DG, Hwang JS, Kim Y (2011) Structure and function of Papiliocin with antimicrobial and anti-inflammatory activities isolated from the Swallowtail Butterfly, Papilio xuthus. J Biol Chem 286(48):41296-41311

Kim H, Jang JH, Kim SC, Cho JH (2014) De novo generation of short antimicrobial peptides with enhanced stability and cell specificity. J Antimicrob Chemother 69(1):121-132

Lee J, Lee DG (2008) Structure-antimicrobial activity relationship between pleurocidin and its enantiomer. Exp Mol Med 40(4):370-376

Maisetta G, Di Luca M, Esin S, Florio W, Brancatisano FL, Bottai D, Campa M, Batoni G (2008) Evaluation of the inhibitory effects of human serum components on bactericidal activity of human beta defensin 3. Peptides 29(1):1-6

Marr AK, Gooderham WJ, Hancock RE (2006) Antibacterial peptides for therapeutic use: obstacles and realistic outlook. Curr Opin Pharmacol 6(5):468-472

Molhoek EM, van Dijk A, Veldhuizen EJ, Haagsman HP, Bikker FJ (2011) Improved proteolytic stability of chicken cathelicidin-2 derived peptides by D-amino acid substitutions and cyclization. Peptides 32(5):875-880

Peterson LR, Gerding DN, Johnson MM, Cherne JE, Opfer BJ, Hall WH (1980) Evaluation of a commercial microdilution system for quantitative susceptibility testing of aminoglycosides against multidrug-resistant GramNegative Bacilli. Antimicrob Agents Chemother 17(1):20-23
Reddy KV, Yedery RD, Aranha C (2004) Antimicrobial peptides: premises and promises. Int J Antimicrob Agents 24(6):536-547

Sharma P, Sharma JD (2001) In vitro hemolysis of human erythrocytes by plant extracts with antiplasmodial activity. J Ethnopharmacol 74(3):239-243

Silva PM, Gonçalves S, Santos NC (2014) Defensins: antifungal lessons from eukaryotes. Front Microbiol 5:97

Souza BM, Mendes MA, Santos LD, Marques MR, César LM, Almeida RN, Pagnocca FC, Konno K, Palma MS (2005) Structural and functional characterization of two novel peptide toxins isolated from the venom of the social wasp Polybia paulista. Peptides 26(11):2157-2164

Steckbeck JD, Deslouches B, Montelaro RC (2014) Antimicrobial peptides: new drugs for bad bugs? Expert Opin Biol Ther 14(1):11-14

Wang K, Dang W, Xie J, Zhu R, Sun M, Jia F, Zhao Y, An X, Qiu S, Li X, Ma Z, Yan W, Wang R (2015) Antimicrobial peptide protonectin disturbs the membrane integrity and induces ROS production in yeast cells. Biochimica Et Biophysica Acta-Biomembranes 1848(10):2365-2373

Wang K, Zhang B, Zhang W, Yan J, Li J, Wang R (2008) Antitumor effects, cell selectivity and structure-activity relationship of a novel antimicrobial peptide polybia-MPI. Peptides 29(6):963-968

Wang K, Yan J, Zhang B, Song J, Jia P, Wang R (2009) Novel mode of action of polybia-MPI, a novel antimicrobial peptide, in multi-drug resistant leukemic cells. Cancer Lett 278(1):65-72

Wang K, Yan J, Chen R, Dang W, Zhang B, Zhang W, Song J, Wang R (2012) Membrane-active action mode of Polybia-CP, a novel antimicrobial peptide isolated from the venom of Polybia paulista. Antimicrob Agents Chemother 56(6):3318-3323

Wang K, Yan J, Dang W, Liu X, Chen R, Zhang J, Zhang B, Zhang W, Kai M, Yan W, Yang Z, Xie J, Wang R (2013) Membrane active antimicrobial activity and molecular dynamics study of a novel cationic antimicrobial peptide polybia-MPI, from the venom of Polybia paulista. Peptides 39:80-88

Wang K, Yan J, Dang W, Xie J, Yan B, Yan W, Sun M, Zhang B, Ma M, Zhao Y, Jia F, Zhu R, Chen W, Wang R (2014) Dual antifungal properties of cationic antimicrobial peptides polybia-MPI: membrane integrity disruption and inhibition of biofilm formation. Peptides 56:22-29

Wang K, Jia F, Dang W, Zhao Y, Zhu R, Sun M, Qiu S, Zhu Y, Yan J, Kong Z, Yan W, Wang R (2016) Antifungal effect and action mechanism of antimicrobial peptide polybia-cp. J Pept Sci 22(1):28-35

Wei GX, Bobek LA (2005) Human salivary mucin muc7 12-mer-l and 12-mer-d peptides: antifungal activity in saliva, enhancement of activity with protease inhibitor cocktail or edta, and cytotoxicity to human cells. Antimicrob Agents Chemother 49(6):2336-2342

Yan J, Wang K, Chen R, Song J, Zhang B, Dang W, Zhang W, Wang R (2012) Membrane active antitumor activity of NK-18, a mammalian NK-lysinderived cationic antimicrobial peptide. Biochimie 94(1):184-191

\section{Submit your manuscript to a SpringerOpen ${ }^{\circ}$ journal and benefit from:}

- Convenient online submission

- Rigorous peer review

- Immediate publication on acceptance

- Open access: articles freely available online

- High visibility within the field

- Retaining the copyright to your article

Submit your next manuscript at springeropen.com 